\title{
СУЧАСНІ СВІТОВІ ПРАКТИКИ ОЦІНЮВАННЯ ЯКОСТІ ОСВІТНЬОЇ ДІЯЛЬНОСТІ ЗАКЛАДІВ ЗАГАЯЬНОЇ СЕРЕДНЬОЇ ОСВІТИ
}

У статті розкрито сучасні світові практики оцінювання якості освітньої діяльності закладів загальної середньої освіти в Україні, Фінляндї, Чехї̈, Сінгапурі.

Автором статті проаналізовано проблеми реалізації функції контролю: порушення балансу між оцінюванням результативності діяльності організациї та урахуванням інтересів працівників, формалізація контролю тощо. Визначено, що внутрішкільний контроль як складова управлінської діяльності є системою вивчення всіх аспектів діяльності закладу загальної середньої освіти з метою виявлення фактичного стану справ та запровадження заходів щодо покращення якості освіти.

Оцінювання освітніх і управлінських процесів у закладах загальної середньої освіти в Україні здійснюеться відповідно до компонентів внутрішньої системи забезпечення якості освіти, встановлених критеріїв та індикаторів із застосуванням адекватного інструментарію збору інформації.

У фінській системі освіти обов'язковою складовою робочого плану є визначення сфер діяльності, щео підлягають самооцінюванню, встановлення якісних або кількісних критерїв оцінювання та планування зміни з удосконалення діяльності закладу освіти на основі результатів оцінювання.

У чеській системі освіти оцінювання діяльності школи розглядають як поетапний процес: визначення предмета і цілей контролю, визначення критерїв та індикаторів, отримання даних для визначення похибки, оцінювання, реалізація результатів.

Сінгапурській освітній системі властива розвинена культура $і$ структура підзвітності, щз реалізуеться у форматі «Модель удосконалення школи» (SEM, 2000), i передбачае відстеження основних показників діяльності иколи за двома категоріями: «Можливості» $i$ «езультати».

У статті зроблено висновок про те, що складовою всіх процесів забезпечення якості $\epsilon$ оцінювання, ще об'єднуе дві споріднені цุілі - підзвітність і підвищення якості.

Ключові слова: якість освітньої діяльності, оцінювання, контроль, управління, світові освітні системи.

Постановка проблеми. Нові інформаційні технології, розвиток сфери послуг, величезна роль людського капіталу в соціально-економічному розвитку держави поновому актуалізують питання забезпечення якості освіти. 3 огляду на це, нині здійснюється перехід від процедур зовнішнього контролю якості діяльності закладів освіти до постійної внутрішньої самооцінки і самовдосконалення за допомогою системи управління якістю.

Аналіз основних документів із забезпечення якості освіти в європейському освітньому просторі свідчить, що в основі всіх процесів забезпечення якості лежать дві споріднені цілі - підзвітність і підвищення якості. Разом вони формують довіру до роботи закладів освіти. Успішно впроваджена система забезпечення якості має створити інформаційне поле як для учасників освітнього процесу, так і для громадськості щодо надання об'єктивних даних про належну якість освіти та освітньої діяльності закладу (підзвітність), а також даватиме поради і рекомендації щодо мождивих шляхів

*C) Жорова I. Я.

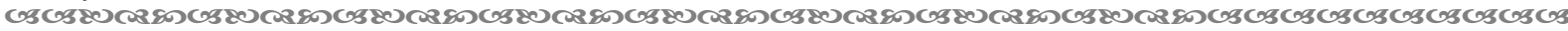
196 
удосконалення його роботи (підвищення якості). Таким чином, забезпечення якості і підвищення якості є взаємопов'язаними процесами. Вони здатні підтримати розвиток культури якості, до якої зможуть додучитися всі - від учнів і педагогів до керівників закладів освіти [6]. Конструктивний пошук шляхів ефективної системи оцінювання освітньої діяльності шкоди актуалізуе дослідження кращих світових практик 3 метою імплементації конструктивного досвіду в сучасну освітню галузь.

Аналіз досліджень. Серед основних досліджень, в яких розкрито питання оцінювання якості освітньої діяльності закладів загальної середньої освіти, доцільно відзначити праці І. Боднар, В. Громового, С. Павдютенкова, А. Покка, Т. Сорочан, Ї.Трунди, В. Ястребової та інших освітніх менеджерів і науковців.

Мета статті - висвітлення сучасних практик оцінювання якості освітньої діяльності шкіл у різних країнах світу.

Виклад основного матеріалу. Реформування національної системи освіти вимагає впроваджень, що забезпечують отримання максимально наближених до вимог сучасного суспільства результатів освітнього процесу. Нову парадигму освіти, принципи та механізми їі запровадження визначено у Законі України «Про освіту», де змістовно перетинаються такі категорії, як: якість освіти, якість освітньої діяльності, система забезпечення якості освіти.

На основі інтеграції та взаємозв'язку цих понять якість освіти визначається як відповідність результатів навчання встановленим вимогам у процесі ефективної взаємодії суб'єктів освітнього процесу в інституційному освітньому середовищі, а забезпечення якості імплементується у всі види діяльності закладу освіти в рамках безперервного циклу вдосконалення (забезпечення та підвищення якості).

У процесі забезпечення якості має бути організовано таке освітне середовище, в якому зміст програм, навчальні можливості та матеріально-технічні засоби відповідають поставленій меті. Зважаючи на це, перед керівником закладу освіти стоять завдання динамічно розвивати зміст освітнього процесу, підвищувати його ефективність і якість. Трансформація функцій і умов діяльності сучасної школи зумовдюють оновлення підходів до оцінювання якості освітньої діяльності та змісту управлінських функцій (планування, організація, мотивація, контроль).

Заключною функцією власне управлінського циклу, що знаходиться у площині оцінювальних процесів, є функція контролю, яка полягає у визначенні ступеня досягнення цілей та реалізації завдань, поставлених перед закладами освіти на етапі планування. Реалізація цієї функції охоплюе всі ланки освітнього процесу i здійснюється на основі єдиних критеріїв і методів відповідно до законодавства та локальних нормативних актів закладу освіти. Необхідно підкреслити, що однією 3 найважливіших умов реалізації функції контролю та оцінювання якості освітньої діяльності є орієнтація керівника як на результати діяльності, так і на дюдей. Зміщення акцентів у той або інший бік призводить до зниження ефективності управління [1, с. 9].

Сьогодні у вирішенні цього питання, як показує досвід, є дуже багато проблем, які проявляються в тому, що, з одного боку, керівники закдадів освіти під час здійснення функції контродю пріоритетом визначають досягнення мети організації без урахування інтересів співробітників. 3 іншого боку, педагоги не повною мірою усвідомлюють задачі організації і не завжди готові працювати так, щоб відстоювати не тільки свої власні інтереси, але й інтереси своєї організації.

Інша проблема, яка виникає при здійсненні контролю в навчальних закладах, - це проблема «жорсткого» формального контролю з боку багатьох керівників без надання відповідної організаційно-методичної допомоги і без бажання зрозуміти конкретну ситуацію, в якій перебуває той, кого «контродюють». Це часто призводить до формування негативної установки в багатьох педагогів щодо контролю як такого й зумовлюе появу тези про те, що контродь як складова за сьогоднішніх умов демократизації управління взагалі не потрібний. Разом 3 тим, аналіз літератури і досвіду

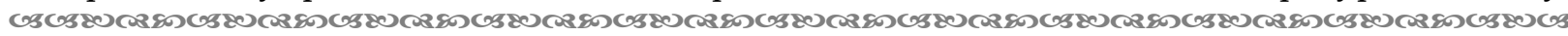


діяльності кращих освітніх організацій та організацій, що функціонують в інших соціальних сферах, доводить, що контроль $є$ необхідною й обов'язковою умовою ефективного управління. Інша справа, в який спосіб буде визначатися його мета і в яких організаційних формах він буде здійснюватися [1, с. 9].

Особливості здійснення внутрішнього контролю були предметом досліджень багатьох науковців. Незважаючи на те, що система контродю є важливою складовою управління освітньою діяльністю в закладі освіти, однозначного визначення поняття контродю щодо діяльності освітніх закладів у науковій, навчально-методичній літературі немає. Узагадьнюючи результати досліджень, I. Боднар визначає, що внутрішньошкільний контроль - це глибоке вивчення всіх аспектів діяльності школи, система перевірок відповідності освітнього процесу державним вимогам, його результативності з метою виявлення фактичного стану справ, порівняння досягнутого 3 очікуваними результатами та вироблення необхідних коригуючих заходів 3 метою покращення результатів навчально-виховного процесу [там само, с. 15]. Ю.Корнажевський вважає, що «педагогічний контроль - це не просто акт механічної перевірки відповідності нормі, стандарту, а «вмотивованість дюдини працювати якісно, осмислювати мету та завдання діяльності, що приводить до іï цілеспрямованості, створення всіх необхідних умов для якісної роботи» [там само, с. 12].

В.Ястребова визначає фактори, передбачені Законом України «Про освіту», які зумовлюють потребу у змінах внутрішнього контролю закладу освіти:

1. Запровадження внутрішньої системи забезпечення якості освіти, що багато в чому визначає напрями внутрішнього контролю.

2. Покладання відповідадьності за якість освіти безпосередньо на керівника закладу освіти, відповідно до основних засад автономії закладу освіти та ніведювання функції зовнішнього інспектування із органів державного управління.

3. Визначення академічної свободи вчителя, що застерігає адміністрацію закладу освіти від втручання у педагогічну діяльність, передбачає вільний вибір учителем форм, методів і засобів навчання, що відповідають освітній програмі.

4. Здійснення контродю за деякими аспектами діяльності закладів освіти органами самоврядування та громадськими організаціями в умовах демократизації управління.

5. Зростання значення педагогічної ради в управлінні закладом освіти. Зокрема, щодо затвердження внутрішньої системи забезпечення якості освіти [7].

На сучасному етапі розвитку національної системи освіти оцінювання якості освіти та освітньої діяльності школи здійснюеться шляхом поєднання внутрішніх (самооцінювання) і зовнішніх (інституційний аудит) процедур. 3 метою забезпечення їх кореляції при плануванні й організації самооцінювання і внутрішнього контрою у закладі освіти також необхідно враховувати напрями освітніх і управлінських процесів закдаду освіти, що підлягають оцінюванню у процесі здійснення інституційного аудиту: освітне середовище закладу освіти; система оцінювання здобувачів освіти закладу освіти; педагогічна діяльність педагогічних працівників закладу освіти; управлінські процеси закладу освіти.

Процедура внутрішнього оцінювання освітніх і управлінських процесів здійснюється відповідно до встановлених закладом освіти критеріїв та індикаторів із застосуванням адекватного інструментарію збору інформації. Слід зазначити, що основою можуть слугувати розроблені Державною службою якості освіти України механізми оцінювання, уточнені відповідно до потреб закладу.

Нормативно-правові документи в галузі шкільної освіти визначають необхідність щорічного самооцінювання, що може бути комплексним, за напрямами, рівнями освіти або іншою моделлю, що враховуе особливості закладу освіти [3].

Аналіз нормативно-правових документів і сучасної практики оцінювання управлінських та освітніх процесів в українській школі свідчить про зміну парадигми,

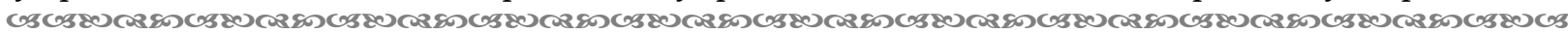
198 
механізмів внутрішкільного контролю та спрямування генеральної мети на підвищення якості.

У фінській системі сформована культура якості, що передбачає формування об'єктивного інформаційного поля для учасників освітнього процесу і громадськості та вироблення рекомендацій з удосконалення освітньої діяльності школи. Зокрема, робочий план школи є основним документом, що визначає цілі навчального року, регламентує всі напрями діяльності школи та є інструментом спільного планування всіма учасниками освітнього процесу. Слід зазначити, що при складанні річного плану школи результати оцінювання попередніх робочих планів шкільною спільнотою визначають зміни в діяльності закладу освіти, оскільки оцінювання без ефективних заходів з удосконалення нівелює саму мету оцінювання.

Обов'язковою складовою робочого плану є визначення сфер діяльності, що підлягають самооцінюванню, визначення якісних або кількісних критеріїв оцінювання [5, c. 77].

У чеській системі оцінювання діяльності закладу освіти розглядають як поетапний процес:

1. Визначення предмета і цілей контродю. На цьому етапі важдиво визначити що саме і з якою метою буде контродюватися. Проміжні цілі контродю повинні відповідати основній меті - успішна робота закладу освіти.

2. Визначення критеріїв та індикаторів. Поряд із встановленням критеріїв, що визначаються правовими нормами, необхідно встановити критерії та індикатори контродю процесів, що пов'язані з реалізацією візії школи та організацією освітньої діяльності. Якщо об'єктами контролю є явища, які залежать від багатьох змінних факторів і є складними для вимірювання, то в якості критеріїв встановдюються аспекти порівняння.

3. Отримання даних для визначення похибки. Передбачає визначення інструментарію для отримання об'єктивних даних, що характеризують безпосередньо предмет контролю, а не інтерпретацію оцінювання іншими особами.

4. Оцінювання. Об'єктивність формулювання оціночних суджень забезпечується чітким порівнянням отриманих результатів із встановленими критеріями. До реалізації цього етапу може бути залучена стороння особа. Такий підхід забезпечує викдючення особистого досвіду участі у контродьованих явищах, унемождивдює знання контексту та заангажованість.

5. Реалізація результатів. Функція контролю на цій стадії перетинається 3 такими функціями управління, як: планування, прийняття рішень та впровадження і $е$ початком управлінського циклу [2, с. 131-136].

Сінгапурська освітня системи позначена розвиненою культурою і структурою підзвітності. Головною системою підзвітності в державі визначено «Модедь удосконалення школи» (SEM, 2000), що запроваджена на заміну системи шкільного інспектування. Відповідно до зазначеної моделі проводиться систематичне самооцінювання, визначаються сфери можливого удосконалення та здійснюеться порівняння 3 подібними школами. Відстеження основних показників діяльності шкоди здійснюється за двома категоріями: «Мождивості» (охоплюе компоненти шкільної культури, процесу та ресурсів і спрямована на оцінювання процесів досягнення результатів), «Результати» (зосереджена на оцінюванні головних результатів роботи шкільної спільноти). Результати самооцінювання підлягають зовнішньому оцінюванню кожні п'ять років. Сдід зазначити, що оцінка діяльності або окремих напрямів роботи школи грунтується викдючно на встановлених фактах. Постійне вдосконалення процесів в закладі освіти також підтверджується фактами.

Особливістю сінгапурської системи освіти є зміщення балансу підзвітності у бік моральної відповідальності за якість освіти як основу майбутнього країни [4, с. 85]. 
Висновки. Оцінювання освітніх та управлінських процесів у закладах загальної середньої освіти в Україні здійснюеться відповідно до компонентів внутрішньої системи забезпечення якості освіти, встановлених критеріїв та індикаторів із застосуванням адекватного інструментарію збору інформації.

У фінській системі освіти обов' язковою складовою робочого плану є визначення сфер діяльності, що підлягають самооцінюванню, встановлення якісних або кількісних критеріїв оцінювання та планування зміни з удосконалення діяльності закладу освіти на основі результатів оцінювання.

У чеській системі освіти оцінювання діяльності школи розглядають як поетапний процес: визначення предмета і цілей контролю, визначення критеріїв та індикаторів, отримання даних для визначення похибки, оцінювання, реалізація результатів.

Сінгапурська освітня системи позначена розвиненою культурою і структурою підзвітності, що реалізується у форматі «Модель удосконалення шкоди» (SEM, 2000), передбачає відстеження основних показників діяльності школи і здійснюеться за двома категоріями: «Мождивості» і «Результати».

Аналіз світових практик оцінювання якості освітньої діяльності закладів загальної середньої освіти свідчить, що складовою всіх процесів забезпечення якості є оцінювання, яке об’єднує дві споріднені цілі: підзвітність і підвищення якості.

Здійснений аналіз не вичерпуе всіх аспектів досліджуваної проблеми і засвідчує необхідність подадьшого вивчення світового досвіду щодо парадигми та механізмів оцінювання освітньої діяльності з метою імплементації кращих здобутків у практику роботи української школи.

\section{Список використаних джерел:}

1. Аудит і оцінювання управління діяльністю загальноосвітнього навчального закдаду / уклад. Боднар I. Є. Кам’янець-Подільський : ПП Буйницький О.А., 2008. 184 с.

2. Директор школи - нові виклики та можливості / Трунда Ї., Троян В., Бржіза К., Бачинська $Є$. Прага : Asociace pro mezinárodní otázky, 2017. 240 c.

3. Методичні рекомендації з питань формування внутрішньої системи забезпечення якості освіти у закладах загальної середньої освіти: затверджено наказом Міністерства освіти і науки України від 30.11.2020 p. № 1480. URL: https://zakon.rada.gov.ua/rada/show/v1480729$20 \#$ Text.

4. Пак Т. И. Переймаючи досвід Сінгапуру. Сила парадоксів / пер. 3 ангд. О.М. Назарової. Харків : Ранок, 2019. 208 с.

5. Покка Арі. Вищий клас. Шкільне управління по-фінські / пер. 3 англ. О. М. Назарової. 2-ге вид., випр. Харків : Ранок, 2019. 169 с.

6. Стандарти і рекомендації щодо забезпечення якості в Европейському просторі вищої освіти (ESG). Київ : ТОВ «ЦС», 2015. 32 с.

7. Ястребова В. Я. Внутрішній контроль у закладі освіти. URL: http://yastrebova49.blogspot.com/.

\section{References:}

1. Bodnar, I. Ye. (Ed.). (2008). Audyt i otsiniuvannia upravlinnia diialnistiu zahalnoosvitnoho navchalnoho zakladu [Auditing and evaluation of the management of the activities of a secondary educational institution]. Kamianets-Podilskyi: PP Buinytskyi O. A. [in Ukrainian].

2. Trunda, Yi., Troian, V., Brzhiza, K., \& Bachynska, Ye. (2017). Dyrektor shkoly - novi vyklyky ta mozhlyvosti [School director - new challenges and opportunities]. Pragha: Asociace pro mezinárodní otázky [in Ukrainian].

3. Methodological recommendations on the formation of an internal system for ensuring the quality of education in secondary education institutions: approved by the order of the Ministry of education and science of Ukraine dated November 30, 2020 No 1480. Retrieved from https://zakon.rada.gov.ua/rada/show/v1480729-20\#Text [in Ukrainian].

4. Pak, T. Y. (2019). Pereimaiuchy dosvid Sinhapuru. Syla paradoksiv [Taking the experience of Singapore. The Power of paradoxes]. (O. M. Nazarovoi, Trans.). Kharkiv: Ranok [in Ukrainian]. 
5. Pokka, A. (2019). Vyshchyi klas. Shkilne upravlinnia po-finski [Top class, Finnish school leadership and management]. (O. M. Nazarovoi, Trans.). Kharkiv: Ranok [in Ukrainian].

6. Standarty i rekomendatsii shchodo zabezpechennia yakosti v Yevropeiskomu prostori vyshchoi osvity (ESG) [Standards and recommendations for quality assurance in the European Higher Education field (ESG)]. (2015). Kyiv: TOV «CS» [in Ukrainian].

7. Yastrebova, V. Ya. Vnutrishnii kontrol u zakladi osvity [Internal control in an educational institution]. Retrieved from http://yastrebova49.blogspot.com/ [in Ukrainian].

\section{Zhorova I. Ya., orcid.org/0000-0003-4304-4962 \\ MODERN WORLD PRACTICES FOR ASSESSING THE QUALITY OF EDUCATIONAL ACTIVITIES OF SECONDARY EDUCATION INSTITUTIONS}

The article covers modern world practices of assessing the quality of educational activities of secondary educational institutions in Ukraine, Finland, Czech Republic and Singapore.

The author of the article analyzed the problems of implementing the control function: the imbalance between assessing the performance of the organization and balance between workers' and employers' interests, formalization of control, etc. It is determined that school internal control as a component of management activities is a system of studying all aspects of the activities of a secondary education institution in order to identify the actual state of affairs and introduce measures to improve the quality of education.

The evaluation of educational and management processes in secondary education institutions in Ukraine is carried out in accordance with the components of the internal system of educational quality assurance, established criteria, and indicators using adequate information collection tools.

In the Finnish education system, a mandatory component of the work plan is the identification of areas of activity to be self-evaluated, the establishment of qualitative or quantitative evaluation criteria, and the planning of changes to improve the activities of the educational institution based on the results of the assessment.

In the Czech system, assessment of educational institution performance is considered as a stageby-stage process: defining the subject and objectives of control, defining criteria and indicators, obtaining data for defining abstractions, evaluation, and implementation of results.

Singapore's educational system is marked by a well-developed culture and accountability framework implemented in the School Improvement Model (SEM, 2000) format, and includes the tracking of the main indicators of school performance in two categories: "Opportunities» and «Results».

The article concludes that assessment is a part of all quality assurance processes and combines two controversial objectives - performance and quality improvement.

Key words: quality of educational performance, evaluation, control, management, world educational systems.

Дата надходження статті: 18.01.2021 p. Рецензент: доктор педагогічних наук, професор Данилюк С. С. 